\title{
Usage of Edible Aquatic Insects for Feed Rations of Poultry Animals
}

\author{
Mehmet Bektas (Corresponding Author) \\ Hinis Vocational School, Department of Veterinary Health and Laboratory, \\ Ataturk University, Hinis, 25600, Erzurum, TURKEY. \\ E mail: mbektash25@gmail.com \\ Olcay Guler \\ Hinis Vocational School, Department of Veterinary Health and Laboratory, \\ Ataturk University, Hinis, 25600, Erzurum, TURKEY.
}

\begin{abstract}
With the rapidly increasing population of people today, mass production, inexpensive labor, low cost, high market share and economic sufficiency are the first issues that come to mind in poultry farming. The most important cost in the poultry farming sector is production of food. As insects are in the richest group that provides species variations in the feeds for living beings, they are a significant source of feeding poultry animals. In addition to this, it is believed that aquatic insects (Coleoptera) are a source with very high protein contents that is used in poultry husbandry. The levels of edible insect consumption are only known by some people in the world. In feeding hens, hen feeds may be experimentally used by mixing these with other edible insect groups that are easier to obtain. As it is possible to use edible insects as protein sources in human consumption, these may also be utilized in feeding poultry animals that are grown for eggs. Our aim for the future is to develop alternative methods that aim to enrich the quality of meat and eggs from poultry animals and conduct a study that provides statistical analysis results regarding hematological, biochemical and economic data. Moreover, we expected to see whether or not there would be potential health risks related to the consumption of these mixed feeds by laying hens and broilers. Consequently, the purpose of this review study is to provide information about edible aquatic insect species which are more economical and practical.
\end{abstract}

Keywords: Broiler, Entomophagy, Poultry Animal, Edible Aquatic Insects.

DOI: $10.7176 / \mathrm{JSTR} / 5-5-9$

\section{Introduction}

In order to meet the needs of three-dimensional foods by the increasingly high human population in the world, a new feeding trend has been developed under the category of edible insects to include synthetic meet, genetically modified foods and some insects. The factors that have led to changes in raw materials of foods and nutritional strategies may include increased human population, reduced interest in plantbased production and animal husbandry, irresponsible nutrition, excessive household wastes and waste of food (Güneş et al.,2017).

Hunger may be defined as insufficient nutrition in terms of protein/energy or micronutrients (vitamins and minerals). Approximately $33 \%$ of the world's population face hunger. The factors that prevent people from sufficient consumption of nutrients may be listed as the stability issues of edible substances and existing raw materials of food (Ekşi and İşci, 2012).

The daily diets of people who live in large cities in developed countries with higher levels of prosperity and broader spectrum of foods contain more protein than those of people living in rural areas. Commercial production of chicken products has reached a level that is affordable by middle economic classes in countries with low income (Table 1). Infrastructure and other related processes for broiler production are created fast, and it is possible to transition to serial production. While chicken meat is not very healthy, it is the most inexpensive one among those obtained from farm animals (FAO, 2013b). Main idea is to evaluate usage of edible aquatic insects for feed rations of poultry animals and is to add more comprehensive approach to poultry industrial spatial newly and clearly. Poultry market are

70 | P a g e

www.iiste.org 
important to need of nutrition at both human feeding and other animal whose nutrition requirement. At this respect, there is a necessity to explain of gain favour in use of edible aquatic insects. Moreover, these inforamations should be added: worldwide, nearly 1700 insect species are reported to be used as human food. Table 1 identifies them according to taxonomic orders, common English names and number of species. Four insect orders predominate, in rank sequence: Coleoptera, Hymenoptera, Orthoptera and Lepidoptera, accounting for 80 percent of the species eaten (Ramos-Elorduy 2005).

Table 1. Chicken meat production by years in some countries (thousand tons) (Anonymous, a).

\begin{tabular}{|l|l|l|l|}
\hline & 2014 & 2015 & 2016 \\
\hline USA & 17,306 & 17,971 & 18,283 \\
\hline BRAZIL & 12,692 & 13,146 & 13,605 \\
\hline CHINA & 13,000 & 13,400 & 12,700 \\
\hline EU & 10,450 & 10,810 & 11,070 \\
\hline INDIA & 3,725 & 3,900 & 4,200 \\
\hline RUSSIA & 3,260 & 3,600 & 3,750 \\
\hline MEXICO & 3,025 & 3,175 & 3,270 \\
\hline ARGENTINA & 2,050 & 2,080 & 2,100 \\
\hline TURKEY & 1,894 & 1,909 & 1,900 \\
\hline THAILAND & 1,570 & 1,700 & 1,780 \\
\hline INDONESIA & 1,565 & 1,625 & 1,640 \\
\hline OTHERS & 16,018 & 15,378 & 15,250 \\
\hline WORLD & 86,555 & 88,694 & 89,548 \\
\hline
\end{tabular}

Net protein utilization (NPU) is a protein quality index that is calculated by the biological value and protein digestibility values of foods. The net protein utilization values of grains are usually lower than $40 \%$. Rice, which has an NPU value of $60 \%$, is an exception, but its absolute protein content is low (7.5\%). The NPU value of chicken eggs is $87 \%$. In general, grains are very poor in terms of essential amino acids that are crucial for human nutrition such as lysine, methionine that contains sulfur, cystine and occasionally tryptophan. Eggs and meat of chicken are rich in essential amino acids (FAO, 2013b).

\section{The Current State of Poultry Farming}

As the methods of scientific nutrition have been developing since 1970s, with some regulations that provided advantages, Turkey, which has taken the 10th place in the world's chicken meat production, has also reached the 14th place in egg production (Çelik and Şengül, 2001; Şahin et.al., 2014).

A study in Turkey reported that, by the year 2015, 1900 species of insects worldwide were edible and could be used as sources of protein. Flies, flour beetles, silk worms, cockroaches, crickets and termites may be used in sectors that are important for human life such as foods, medicine and textile in addition to utilization as animal feeds. Insects are also used in foods as dyes (E120 carmine), protective films and coatings (E904) Shellac (Coccus lacca) (Güneş et al.,2017).

Despite such a speed up and mobility in production, there may sometimes be significant deficiencies in the system, and the Turkish chicken meat sector imports $40 \%$ of the total raw material production from other countries (Tavuk Eti Tarım Ürünleri Piyasalari, 2018).

\section{Advantages of Consumption of Edible Insects by Chickens}

Chickens are omnivorous animals that usually feed on arthropod species (mosquito larvae, grasshoppers, louses, etc.) (Tekeli, 2014).

Chickens play an important role in the poultry farming industry as a leading market and provide protein and fat-free and healthy meat for people. This is why providing the nutrients that chickens need is important for them to reach their optimal level of production (Mngq1, 2015).

In the agricultural sector, various chemical insecticides are used to control the pest insects worldwide. However, these heavy chemical substances also inflict significant harm on nature and organisms that are not targets (Iskender and Algur, 2009). By feeding poultry animals with insects, there may be a reduction in the population of insects, and this way, insecticides could be used less, and the damages on the environment could be minimized (Figure 1, c). 
While fly larvae as food for chickens facilitate the recycling of animal-based fertilizers, not only are chickens fed, but also organic wastes are recycled (Sert, 2003).

Likewise, Fanatico (1998) reported that poultry animals that fed in meadows decreased feed costs by $30 \%$ by feeding on seeds, insects and worms.

It is possible to reach the general conclusion in studies that have been carried out in the world that meat yield and live weight increased in chickens that were fed by diets containing worms by $10 \%$ to $15 \%$, the time of reaching marketable weight was shortened, and these ratios were appropriate for feeding broiler chickens. Additionally, when chickens were fed by diets that included $5 \%$ and $20 \%$ worms, this significantly increased the breast muscles of the animals (Hwengbo et al., 2009).

Pretorius (2011) reported that, in comparison to chickens that were fed by rations of soybeans, those that were fed by Musca domestica (housefly) larvae had higher increases in live weight and higher feed consumption levels. These larvae did not cause any erosion or toxicity in the gizzards of the chickens. The muscle ratios in the breast and the carcass were higher in the group that was given $10 \%$ housefly larvae in comparison to the group that was fed with soybeans. However, the color and $\mathrm{pH}$ values in the breast and leg muscles were not significantly affected by the interventions.

Furthermore, Pretorius (2011) stated that the orders of Coleoptera and Diptera could be the most suitable organisms for feeding chickens, especially housefly larvae in the order Musca domestica (Diptera) have a broad variety of solid protein contents, and therefore, these may be the potentially most suitable source of protein.

It was discovered at the department of Seroculture at the Tamil Nadu Agricultural University in India that the high levels of wastes in the silk worm industry could be used as feed in broiler production (Huis et al., 2013).

Wang et al. (2005) reported that the body of an adult insect contains $58.3 \%$ crude protein, $10.3 \%$ crude oil, $8.7 \%$ chitin and $2.96 \%$ crude ash. It was stated that poultry feed created by substituting fishcontaining feed with grasshopper flour by $15 \%$ could be prepared and used especially in impoverished geographies without changing the values of live weight, feed consumption and feed utilization in the animals.

Jacob (2013) reported that poultry animals' consumption of some insect species would affect the nutrient contents of their meats and eggs. It was observed that the fat contents of eggs increased in chickens by insect consumption. Consequently, it was determined that fly larvae were an inexpensive feed material that may be used in the place of chicken feed based on fish.

A study on Cirina forda (Diptera) investigated the usability of the larvae of the insect as feed material in feeding poultry animals. In the study, insect larvae were substituted by $50 \%$ and $100 \%$ with fishcontaining feed. As a result of the trial, there was no significant difference between the groups in terms of live weights. Results were reported to state that worms may be a great source of protein in the field of producing poultry meat and eggs, and they will provide a positive influence on the quality and performance of broiler meat (Oyegoke, 2006).

Similarly, Al Qazzaz et al. (2016) fed 9-month-old laying hens with a feed that was enriched in protein by using black soldier fly larvae and reported that there was no significant difference of the time of incubation, but there was a significant increase in the number of chicks that hatched from the eggs.

In difference to the topic of our study, we felt the need to summarize the results of a study which investigated the effects of addition of humate and probiotics into the rations of Japanese quails that are kept in different numbers by different ratios on egg quality and blood parameters. As a result of the study in question, it was reported that increased numbers of animals that are kept affected the animals' live weight changes, egg yield, egg weight and feed utilization rates negatively, and these problems could be eliminated by adding humate and probiotics to the feeds (Yörük et al., 2008).

Briefly, Albers and Camerdese (1992) added that compared were concentrations of $\mathrm{Al}, \mathrm{Cd}, \mathrm{Ca}, \mathrm{Cu}, \mathrm{Fe}$, $\mathrm{Hg}, \mathrm{Pb}, \mathrm{Mg}, \mathrm{Mn}, \mathrm{Ni}, \mathrm{P}$, and $\mathrm{Zn}$ in water, plants, and aquatic insects of three acidified ( $\mathrm{pH}-5.0)$ and three nonacidified ( $\mathrm{pH}-6.5$ ) constructed wetlands. Accumulation of $\mathrm{Zn}$ in water and bur-reed (Sparganium americanum) were higher in acidified wetlands than in nonacidified wetlands. Floating nonrooted plants contained mean concentrations of $\mathrm{Fe}, \mathrm{Mg}$, and $\mathrm{Mn}$ that were higher than recommended maximum levels for poultry feed. The mean concentrations of all metals in insects were below recommended maximum levels for poultry feed and below levels that cause toxic effects in wild birds. Smaller than expected increases of metal concentrations in the water of acidified wetlands were probably due to limited mobilization of metals from the sediments and insignificant changes in sedimentation of aqueous metals. Calcium was lower in acidified than in nonacidified wetland water, but the Ca content of insects and burreed was not lower. Low concentrations of $\mathrm{Ca}$ in aquatic insects from both groups of wet- lands indicate that calcium-rich crustaceans and mollusks are probably important to female water- fowl and their young during the spring, when invertebrates make up the majority of the diet. Although toxic effects from metal

72 | P a g e

www.iiste.org 
ingestion seem to be unlikely consequences of wetland acidification, the adverse effect of low $\mathrm{pH}$ on the occurrence of crustaceans and mollusks could threaten egg produc- tion and development of young.

\section{Usage of Insects as Human Food}

In addition to being kept for various reasons such as the production of goods that are essential such as meat, eggs and milk, animals are also a source of reproduction and breeding of future animal generations (FAO 2013a).

The habit of consuming insects as food is known as "entomophagy," and it is widespread in several places in the world except Europe and North America. Bukkens (2010) stated that, in addition to competing with conventional animal products such as beef and pork, it is greatly important that insects are consumed as snacks by local people, and they are bred only for such purposes.

In contrast to several parts of the world where there is a lack of vitamins, especially vitamin B, calories, minerals and fats, thanks to the consumption of insects that has become a tradition for centuries in Latin American countries, such deficiencies are not experienced (Ramos-Elorduy, 1997).

The place of insects in the continuation of life is undeniable. The importance of insects in the agricultural field is great especially in terms of facilitating the pollination of plants they feed on and helping the distribution of their seeds (Bektaş, 2018). In addition to this, in Japan, several species of insects are not only consumed as food but also sold in shops as canned food and snacks. Canned food is made out of another species, Vespa japonica (Kantha, 1988). In Syria, Saudi Arabia and Egypt, people collect grasshoppers in swarms, fry them, turn them into a powder and make a delicious bread by mixing with flour (Fischer, 1995). The Onabasulu people who live in the north of the Mount Bosavi eat not only the larvae but also the adults of Oryctes centaurus (centaur rhinoceros beetle) (Ratcliffe, 2006).

As known by people, insects are very rich in minerals and vitamins. Caterpillars contain high levels of iron, zinc and vitamin $\mathrm{B}_{12}$. The $\mathrm{Mg}$ and $\mathrm{Cu}$ rates in termites are very high. The larvae of palm weevil are rich in zinc, thiamine and riboflavin. It is seen as a certainty that the high contents of iron and zinc in edible insect species will provide a solution for problems such as iron deficiency caused by nutritional habits of women in some countries (FAO, 2013a)

Entomophagy is a term that refers to consumption of insects as a food source (Bodenheimer, 1951). It may prove that insects, which are cold-blooded living beings, are at the top in comparison to other farm animals in terms of converting the food they eat into body proteins (Huis et al., 2013).

Entomophagy, which will continue to lead food and feed safety in the future, constitutes the main theme of entomological studies since the discovery of the nutritional value of insects, even today (Adeoye et al., 2014; Anankware et al., 2015).

\section{Aquatic Insects}

Generally, when it is discussed that information of aquatic insecs, there are very data about it as noted below:

The Hydrochidae family is a monotypic family that a single genus, Hydrochus Leach, 1817 (Hansen, 1987, 1991). 182 genera are known worldwide in this genus (Tashar, 2017b). They are seen in all zoocographic regions (Archangelsky et al., 2016). Turkey is one of eight known species are endemic (including stone walls, 2017b). They are considered as small and true aquatic insects in lengths of 1,5-6. They live in stagnant or slow flowing waters. They feed on algae and rotten plant materials. The larvae are carnivorous (Endrödy-Younga and Stals, 2008; Archangelsky et al., 2016).

The Dryopidae family is represented by 300 species of 33 genera (Jäch and Balke, 2008; Taşar, 2018a). They are mostly distributed in Oriental and Neotropical regions. They live in various aquatic, semiaquatic and terrestrial habitats (Kodada and Jäch, 1995). Herbivores obtrusive. Adults feed on a variety of substrates, such as leaf debris and billets in the hollow parts of fast-flowing waters (Webster and DeMerchant, 2012). It is known that 11 species are connected to 3 genera from our country (Taşar, 2014a, 2018a).

The Elmidae family has 1497 species connected to 147 genera. It has also been reported that there are 5 fossil records of 2 genera (Jäch et al., 2016). While members of this family generally prefer to live in fast-flowing rivers, some species live in the coastal part of these fast-flowing waters (Jäch and Kodada, 1995). Both adult and larvae are fed with diatoms, decayed algae detritus and vegetable residues (Webster and DeMerchant, 2012). Elmins are aquatic insect species that are sensitive to various pollutants such as agricultural, industrial and household waste. These species are reported to be clean water indicators due to their high sensitivity to pollutants (Braun et al. 2014, Taşar, 2018a).

The Heteroceridae family is known to have 200 species of 5 genera worldwide (Mascagni, 1995; Taşar, 2014a). Members of this family live in muddy or sandy parts of the aquatic habitats. They spend most of their time in the galleries they opened in the land (Clarke, 1973; Aguilera et al., 1998; Mascagni, 1995;

73 | P a g e

www.iiste.org 
Taşar, 2014a). 750 species of the genus Gyrinidae are known from 13 genera worldwide. Both adult and larvae are true aquatic beetles (Garrido et al., 2011).

200 species of 5 genera of the family Haliplidae have been recorded worldwide. Both adults and larvae are reported to live in a wide variety of aquatic habitats (Garrido et al., 2011).

The Noteridae family has recorded 250 species of 14 genera from all over the world. Both adults and larvae are aquatic (Garrido et al., 2011).

According to Huis et al. (2013) several aquatic insects such as the larvae or furniture beetle and both larvae and adults of dung beetle are edible. Ramos-Elorduy (1997) listed 78 species of aquatic insects in the families of Dytiscidae, Gyrinidae and Hydrophilidae. Typically, only the larvae of these species are edible. Palm weevil, which is a frequently encountered pest in tropical geographies such as Africa, South Asia and South America, also known as Rynchophorus, is an insect species that is consumed as food to a great extent. According to Yde Jongema (2015), in eastern countries such as Indonesia, India, Laos, Cambodia, Malaysia and Myanmar, people consumes aquatic insects such as Sternolophus, Hydrophilus (Hydrophilidae), Hydradicus, Laccophilus, Eretes, Cybister and Dytiscus (Dytiscidae).

Defoliart (1995) argued that different consumptions could be observed in Southern Africa, for example, some ants play an important role in the Pedi diet. Oecophylla smaragdina (Formicidae), which is known as red or green tree ants in Asia (India, Burma, Thailand and Papua New Guinea) is consumed in its every stage of life (larva, pupa and adult). These are added into bamboo soup with cooked eggs or offered to guests with fruits in Thailand.

\section{Discussion}

Insects are organisms that play a significant role in human consumption and are traditionally consumed in the cultures of several countries, while they provide significant options as protein sources for communities that experience nutritional deficiencies (Table 2).

Table 2. Show of ordo, groups of taxonomic and family, consumed edible insects and consumption region (from Defoliart 1995 and Jongema 2015).

\begin{tabular}{|c|c|c|c|c|}
\hline Ordo & $\begin{array}{c}\text { Groups of taxonomic } \\
\text { (Known) }\end{array}$ & Family (e.g.) & $\begin{array}{c}\text { Aim to } \\
\text { Consumption }\end{array}$ & $\begin{array}{l}\text { Consumption } \\
\text { Region }\end{array}$ \\
\hline Coleoptera & $\begin{array}{l}\text { more than } 100 \text { genera } \\
\text { in } 17 \text { families }\end{array}$ & $\begin{array}{l}\text {-Cerambycidae } \\
\text {-Curculionidae } \\
\text {-Scarabaeidae, } \\
\text {-Buprestidae } \\
\text {-Dytiscidae }\end{array}$ & As food & $\begin{array}{c}\text {-Indonesia } \\
\text {-Philippines } \\
\text {-Sri Lanka } \\
\text {-Papua New } \\
\text { Guinea } \\
\text {-Western Pacific }\end{array}$ \\
\hline Hymenoptera & plenty of species & $\begin{array}{c}\text {-Apidae (bees) } \\
\text {-Formicidae (ants) } \\
\text {-Vespidae (wasps, hornets) }\end{array}$ & $\begin{array}{l}\text { It is used as } \\
\text { food by } \\
\text { indigenous } \\
\text { populations }\end{array}$ & $\begin{array}{c}\text {-Africa } \\
\text {-Asia } \\
\text {-Australia } \\
\text {-South America } \\
\text {-Mexico }\end{array}$ \\
\hline $\begin{array}{l}\text { Isoptera } \\
\text { (Termites) }\end{array}$ & $\begin{array}{l}\text { at least ten genera in } \\
\text { four families }\end{array}$ & - Termitidae & $\begin{array}{l}\text { It is most } \\
\text { widely used } \\
\text { as food }\end{array}$ & $\begin{array}{c}\text {-Angola } \\
\text {-Senegal } \\
\text {-Ethiopia } \\
\text {-Namibia } \\
\text {-Nigeria } \\
\text {-Mozambique } \\
\text {-South Africa } \\
\text {-Zimbabwe } \\
\text {-Zaire }\end{array}$ \\
\hline Lepidoptera & $\begin{array}{l}\text { approximately } 80 \\
\text { genera in } 20 \text { families } \\
\text { used as food }\end{array}$ & -Saturniidae (giant silk moths) & $\begin{array}{l}\text { as food and/or } \\
\text { animal feed }\end{array}$ & $\begin{array}{c}\text {-Nigeria } \\
\text {-South Africa } \\
\text {-Zambia } \\
\text {-Zimbabwe } \\
\text {-Zaire }\end{array}$ \\
\hline Orthoptera & $\begin{array}{l}\text { are known in more } \\
\text { than } 50 \text { genera in seven } \\
\text { families }\end{array}$ & $\begin{array}{l}\text {-Acrididae } \\
\text { - Gryllidae } \\
\text {-Tettigoniidae }\end{array}$ & $\begin{array}{l}\text { as food and/or } \\
\text { animal feed }\end{array}$ & $\begin{array}{l}\text {-South Africa } \\
\text {-Japan } \\
\text { - Thailand } \\
\text {-Mexico City }\end{array}$ \\
\hline
\end{tabular}


Adequate consumption of edible insects does not only provide essential elements, but it also meets the needs for vitamins that are required for the body. While consumption of insects does not have a place in the Turkish culinary culture, insects are gradually being used as an alternative source of unprocessed raw materials also in the food industry in the world (Figure 1; a and b).
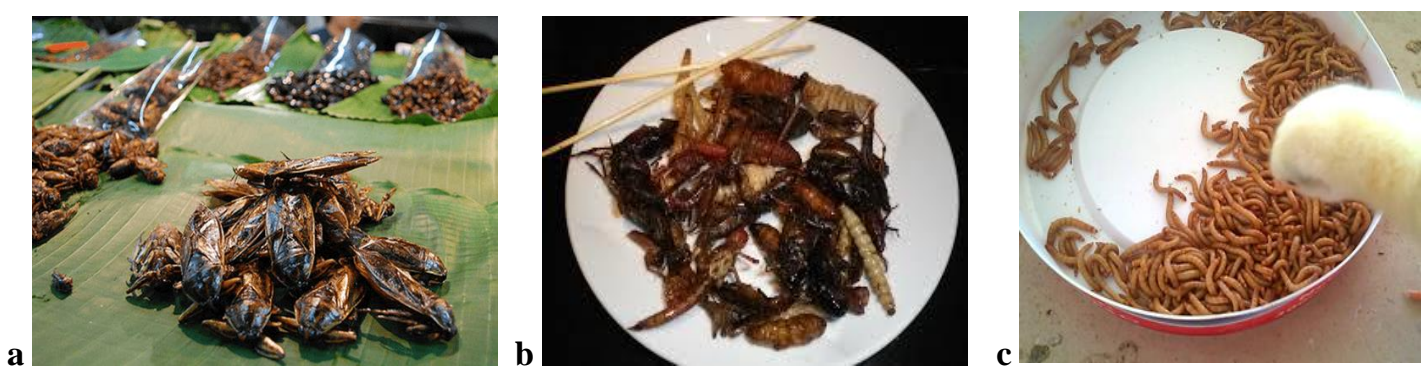

Figure. 1. a. Edible insects sold at markets; b. Edible insects presented as a serving; c. Usage of caterpillars in chick feeds (Anonymous, b).

Environmentally speaking, most Coleoptera species facilitate pollination as they move from one flower to another or one tree to another while moving on the flowers for feeding. However, as they also damage flowers, these species are known as pestilent pollinators (Benedek, 1996).

Because consumption of these types of insects by humans and animals will decrease the number of pestilent pollinators, it will affect the pollination process positively, though not directly.

Additionally, insects' chemical contents may include potential toxic accumulations that may lead to toxicity later. This is why insect consumption should be monitored at controlled consumption levels for both human nutrition and animal feeding.

There is no standard in terms of consumption regarding the nutritional values of insects. The amounts of elements (some heavy elements are also included here) recommended for a person (25-year-old male) for daily intake are variable as seen in Table 3 (Huis et al., 2013).

In addition to this, it is expected that awareness will increase on tendencies towards new methods and mechanisms in insect production for making insects a more practical animal-based protein and reducing labor costs in developing countries. In this context, with this evaluation that was made on the data derived from references, it is expected to contribute to providing job opportunities for those who live in rural and social areas in the economic and social senses and shedding light on new methods and innovative initiatives to promote new ideas on easier and more efficient production.

Table 3. Qualitative presentation of the daily recommendation of intake for a 25 -year-old male (Huis et al., 2013).

\begin{tabular}{|c|c|}
\hline Element & $\begin{array}{c}\text { Recommended intake for a 25-year-old male } \\
\text { (mg per day)* }\end{array}$ \\
\hline Potassium & 4700 \\
\hline Chloride & 2300 \\
\hline Sodium & 1500 \\
\hline Calcium & 1100 \\
\hline Phosphorus & 700 \\
\hline Magnesium & 400 \\
\hline Zinc & 11 \\
\hline Iron & 8 \\
\hline Manganese & 2.3 \\
\hline Copper & 0.9 \\
\hline Iodine & 0.15 \\
\hline Selenium & 0.055 \\
\hline Molybdenum & 0.045 \\
\hline
\end{tabular}

Note: *Dietary reference intakes (DRIs): recommended dietary allowances and adequate intakes, minerals, Food and Nutrition Board, Institute of Medicine, National Academies. 
To use of insects as forage at poultry animals it might been that has been applied for a long time by farmers at random. While livestocks, poultry, broilers and other farm animals feed, it also take in mixed forages and nutritions. At this point, calculate of nutritive values between forage and mixed (insects and herbal) is needed for more quality production. Values of nutritions should take into account one by one, then these advantages should scale due to more efficient results (yields).

In the industrial sense, the number of animals that are bred in a unit area is highly important for the profitability of the business. For example, in intensive poultry breeding, when the production is realized in cage systems, some of the environmental factors that affect the yield characteristics in keeping the animal in cases are related to the characteristics of and conditions in the cage (Yörük et al., 2018). In terms of development of alternative new methods and nutritional options and sustainability, another aim is that concerned individuals should know that alternative protein sources in feeding poultry animals have effects on yield, and new entrepreneurs should be informed on this matter.

Edible insects are important to human nutritions, but applications of mixed forage (insects and herbal) or edible insects at poultry and broiler farms will happen more important for future food source. Because of egg and chicken consumption by humans, feeding of hens should be focused in several research and tentatively productions.

\section{Conclusion}

This review discussed some species in the order of Coleoptera and gathered important information in terms of finding more effective and advanced methods in obtaining feeds for poultry animals and broilers. It is needed to provide more of industrialized edible insects for poultry animals and broiler hens than what they pick up from the environment. More studies are needed to understand whether or not these are safer for consumption. We are aware that these data that will be obtained as a result of the analyses on foods (meat, eggs) that constitute the food chain in the context of the living environment covered by our study will be a source of new industrial investments and studies in the future.

In summary, considering the fact that protein-rich raw materials in both Turkey and the world are expensive, it would be beneficial to state that it is crucial to research new alternative sources. For this reason, industrial establishments in the field of poultry breeding and relevant establishments should conduct research and development activities that focus on edible insects. In similarity to completed studies, it was seen from references that edible insects have very high levels of crude protein, and the findings that have been obtained may provide a solution to nutritional problems.

According to the data above, consumption of insects is necessary for the purpose of preventing a potential famine that may be encountered in the future. However, due to the fact that some insects are hosts of some pestilent microorganisms and some have toxic mineral contents, consumption of insects may be utilized after eliminating these potentially negative impacts. Moreover, consumption of insects may be rejected by people as it is not a traditional behavior for some countries in the world. This is why consumption of insects by poultry animals may get people used to this idea indirectly as an alternative source of food.

When legal arrangements and existing conditions are suitable, and when edible aquatic insects are used as an alternative source of protein, it is believed that this will reduce feeding costs in poultry husbandry, and insects could be kept under control in the environment by preventing them to reproduce excessively.

Note: This study was compiled by examining the references below.

\section{References}

Anonymous, a. 2019. http://www.zmo.org.tr/genel/bizden_detay.php?kod=27145\&tipi=42\&sube=0.

Anonymous, b. 2019. http://www.ediblebugfarm.com/blog/edible-insects-list/.

Adeoye OT, Oyelowo OJ, Adebisi Fagbohhugbe TA, Akinyemi OD. 2014. Eco- diversity of edible insects of Nigeria and its impact on food security. Journal of Bio and Life Sci, 5 (2): 175-187.

Aguilera, P., Mascagni, A., Ribera, I., The family Heteroceridae MacLeay, 1825 (Coleoptera, Dryopoidea) in the Iberian Peninsula and the Balearic Islands. Miscellania Zoologica, 21(1): 75100, (1998).

Anankware PJ, Fenning KO, Osekre E, ObengOfori D. 2015. Insects as food and feed: A review. Int J. of Agri Res and Rev, 3 (1): 143-151.

76 | P a g e

www.iiste.org 
Albers P.H. and Camarde M. B. 1993. Effects of acidification on metal accumulation by aquatic plants and invertebrates. Constructed wetlands. Environmental toxicology and chemistry. Volume: 12 issue: 6 pages: 959-967. Doi: 10.1897/1552-8618(1993)12[959:eoaoma]2.0.co;2. http://apps.webofknowledge.com/full_record.do?product=WOS\&search_mode=GeneralSearch \&qid=11\&SID=F5vImAb6BsatQDROdJx\&page $=1 \&$ doc $=1$.

Al-Qazzaz AMF, Ismail D, Akit H, Lokman HakimIdris L. 2016. Effect of using insect larvae meal as a complete protein source on quality and productivity characteristics of laying hens. R. Bras. Zootec, 45(9): 518-523.

Archangelsky, M., Beutel, R. G., Komarek, A., Coleoptera, Beetles Volume 1: Morphology and Systematics

(Archostemata, Adephaga, Myxophaga, Polyphaga partim) 2nd edition: Chapter 12: Hydrophiloidea Latreille, 1802 231-272 561pp, Walter de Gruyter GMBH, Berlin/Boston, Germany, (2016).

Bayram, S., Mart, A., İncekara, Ü., Polat, A., Taşar, G. E., A faunistic study on the Hydrophilidae in Sivas province (Turkey), Munis Entomology \& Zoology, 7 (2): 881-892, (2012).

Bektaş, M., Polat, A., Incekara, Ü., Taşar, G. E., Adana ili Sucul Kınkanatlı (Polyphaga: Helophoridae ve Hydrophilidae) Faunası, Adıyaman Üniversitesi Bilim, Kültür ve Sanat Sempozyumu, ADYÜ Sempozyum-2015, Özet Bildiriler Kitapçığı, sayfa: 209, AdıyamanTürkiye (2015).

Bektaş M. 2018. Evaluation of some phytophagous insect species' numbers of collection according to months and elevation range for agrucultural struggle in Turkey. Munis Ento Zool, 2018 (2): 597 -603.

Benedek P. 1996. Insect pollination of fruit crops. Floral Biology of Temperate Zone Fruit Trees and SmallFruits (eds. J. Nyeki, M. Soltesz). Akade'miai Kiado, Budapest, Hungaria, 287-341.

Bodenheimer FS. 1951. Insect as human food. W Junk Pub. The hague, 352.

Braun, B. M., Salvarrey, A. V. B., Kotzian, C. B., Pires, M. M., Diversity and distribution of riffle beetle assemblages (Coleoptera, Elmidae) in montane rivers of Southern Brazil. Biota Neotropica 14(2): e20130001, (2014).

Bukkens SGF. 2010. The nutritional value of edible insects. Ecology of Food and Nutrition. (Print) 1543-5237 (Online) Journal homepage: http://www.tandfonline.com/loi/gefn20.

Çelik Y, Şengül T. 2001. Şanlıurfa ili kentsel alanında tüketicilerin yumurta tüketim düzeyleri ve Tüketim alışkanlıklarının belirlenmesi. Hayv Üret, 42 (2): 53-62.

Clarke, R. O. S., Handbooks for the Identification of British Insects Coleoptera Heteroceridae. Royal Entomological Society of London, Volume 5(2): 1-15, (1973).

Defoliart GR. 1995. Edible insects as minilivestock. Biod and Conserv, 4: 306-321.

Ekşi A, İşçi A. 2012. Dünyada açlık olgusu ve çözüm arayışları. Gıda, 37 (1): 39-45.

Endrödy-Younga, S., Stals, R., Guides to the Freshwater Invertebrates of Southern Africa, Volume 10: Coleoptera (Ed: R. Stals \& IJ de Moor) Chapter 9: Hydrochidae, 93-96, 263pp, Republic of South Africa, (2008).

Fanatıco A. 1998. Sustainable egg production. ATTRA. Sustainable chicken production. Online in URL address [http://orgprints.org/10463/01/10463.pdf]

FAO 2013a. http://www.fao.org/docrep/018/i3107e/i3107e.PDF (access date: 18.09.2018).

77 | P a g e

www.iiste.org 
FAO 2013b. Poultry development review. David Farrel. School of Land, Crops and Food Sciences. (1):7-8.The University of Queensland, St. Lucia 4072, Queensland, Australia.

Fischer E. 1995. Ztschr. Ethn. Bd. 80, Heft 1, Braunschweig, 1-37.

Garrido, J., Benetti, J. C., Bilbao, A. P., (Chrysomelidae, Curculionidae, Dryopidae, Dytiscidae, Elmidae, Gyrinidae, Helophoridae, Haliplidae, Hydraenidae, Hydrochidae, Hydrophilidae, Hydroscaphidae, Hygrobiidae, Noteridae, Psephenidae, Scirtidae). Identification Guide of Freshwater Macroinvertebrates of Spain, 21-25, 102-111, Springer Dordrecht, Heidelberg, London, New York, (2011).

Glime, J. M., Aquatic Insects: Holometabola - Coleoptera, Suborder Polyphaga. Chapter 11-10. In: Glime, J. M. Bryophyte Ecology. Volume 2. Bryological Interaction. Ebook sponsored by Michigan Technological University and the International Association of Bryologists, (2015).

Güneş E, Sormaz Ü, Nizamlığlu HF. 2017. Gıda ve turizm sektöründe böceklere yer var mı?. Uluslar Türk Düny Turizm Araştır Derg. Bahar-2017 Cilt: 2 No:163.

Hwangbo J, Hong EC, Jang A, Kang HK, Oh JS, Kim BW, Park BS. 2009. Utilization of house flymaggots, a feed supplement in the production of broiler chickens. J Environ Biol, 30 (4): 609614.

Huis AV, Itterbeeck JV, Harmke Klunder H, Mertens E, Halloran A, Giulia M, Vantomme P. 2013. Edible insects: future prospects for food and feed security. FAO Forestry Paper. http//: edible\%20insects/edepotlink_t519df658_001.pdf.

Iskender N, Algur ÖF. 2009. Sekiz dişli Kabuk Böceği (Ips typographus, Coleoptera: Scolytidae)'nin bakteriyal Florası Üzerine Araştırmalar. Kafkas Üniv Fen Bil Enst Derg. 2(1): 67-76.

Jäch, M. A., Kodada, J., Elmidae: 1. Checklist and bibliography of the Elmidae of China (Coleoptera). pp. 289-298. In: Jäch, M.A., Jl, L. (eds.), Water Beetles of China, Volume 1, (1995).

Jäch, M. A., Balke, M., Global diversity of water beetles (Coleoptera) in freshwater. Hydrobiologia 595: 419-442, (2008).

Jäch, M. A., Kodada, J., Brojer, M., Shepard, W. D., Čiampor Jr, F., World Catalogue of Insects, Volume 14, Coleoptera: Elmidae, Protelmidae. Brill, Leiden, 318p, (2016).

Jacob J. 2013. Including insects inorganic poultry diets. http://www.extension.org/pages/69999/includinginsects-in-organicpoultrydiets\#.U2uEPTPehdg.

Jongema Y. 2015. World list of edible insects. Wageningen university. httpswww.wur.nlupload_mm741ca8baa25-b035-4bd2-9fdc-a7df1405519a_world\%2011st

Kantha SS. 1988. Insect Eating in Japan Nature, 336: 316-317.

Kodada, J., Jäch, M. A., Dryopidae: 1. Checklist and bibliography of the Dryopidae of China (Coleoptera). M.A. Jäch \& L. Jl (eds.): Water Beetles of China, Volume 1: 325-328, (1995).

Mascagni, A., Heteroceridae: Check list of the Heteroceridae of China and neighbouring countries, and description of two new species (Coleoptera). M.A. Jäch \& L. Jl (eds.): Water Beetles of China, Volume 1: 341-348, (1995).

Mngq1 SC. 2015. Effect of Tenebrio molitor larvae as a protein source on growth performance, carcass yield and meat quality of broiler chickens. Masters of Science in Agriculture. Department of Livestock and Pasture Science Faculty of Science and Agriculture, University of Fort Hare. 
Oyegoke OO, Akintola AJ, Fasoranti JO. 2006. Dietary potentials of the edible larvae of Cirina forda (westwood) as a poultry feed. African Journal of Biotechnology, 5 (19): 1799-1802, 2 October 2006 Available online at http://www.academicjournals.org/AJB ISSN 1684-5315.

Pretorius Q. 2011. The Evaluation Of Larvae Of Musca Domestica (Common House Fly) As Protein Source For Broller Production. Stellenbosch University http://scholar.sun.ac.za.

Ratcliffe BC. 2006. Scarb Beetles in Human Culture. Coleopterists Society Monograph, 5: 85-101.

Ramos-Elorduy BJ. 1997. The importance of edible insects in the nutrition and economy of people of the rural areas of Mexico. Ecology of Food and Nutrition, 36:5, 347-366, DOI: 10.1080/03670244.1997.9991524.

Ramos-Elorduy, J. 2005. Insects: a hopeful food source. In M.G. Paoletti, ed. Ecological implications of minilivestock, pp. 263-291. Science Pub., Enfield NH, USA.

Sert O. 2003. Hacettepe.edu.tr Entomoloji Ders not, s:114.

Şahin A, Kutlu HR, Görgülü M. 2004. Organik tavukçuluk: Organik tarım prensiplerine uygun bakım ve besleme ile piliç eti ve yumurta üretimi. 4. Zootekni Bilim Kongresi, 1-3 Eylül 2004, Isparta.

Yörük MA, Laçin E, Hayırlı A, Yıldız A. 2008. Humat ve prebiyotiklerin farklı yerleşim sıklığında yetiştirilen Japon Bıldırcınlarında verim özellikleri, yumurta kalitesi ve kan parametrelerine etkisi. Yyü Vet Fak Derg. 19 (1): 15-22.

Taşar, G. E., A Contribution to the Knowledge of Turkish Dryopidae, Elmidae and Heteroceridae (Coleoptera: Byrrhoidea) Fauna. Archives of Biological Sciences, Belgrade, 66(4): 1473-1478, (2014a).

Taşar, G. E., The occurrence of the subgenus Methydrus Rey, 1885 in Turkey (Coleoptera: Hydrophilidae, Enochrus) with taxonomic and distributional notes. Munis Entomology \& Zoology, 9(1): 478-482, (2014b).

Taşar, G. E., Hydrophiloidea (Coleoptera: Helophoridae, Hydrochidae and Hydrophilidae) Fauna of Adıyaman Province. KSU Journal of Naturel Sciences, 20(2): 103-110, (2017a).

Taşar, G. E., Hydrochus adiyamanensis sp. n. from Adıyaman Province in South-Eastern Turkey (Coleoptera: Hydrochidae). Zoology in the Middle East, 63(4): 356-361, (2017b).

Taşar, G. E., Checklist of Dryopidae and Elmidae (Coleoptera: Byrrhoidea) of Turkey. Biharean Biologist, 12(1): 1-6, Art.\#e171201, (2018a).

Taşar, G. E., Contributions to the knowledge of Aquatic Coleoptera Fauna (Dryopidae, Helophoridae, Heteroceridae, Hydrochidae, Hydrophilidae, Gyrinidae, Haliplidae and Noteridae) of Diyarbakır, Mardin and Batman Provinces (Turkey), Turkish Journal of Fisheries and Aquatic Sciences, 18: 927-936, (2018b).

Tavuk Eti Tarım Ürünleri Piyasaları. 2018. Tarımsal ekonomi ve politika geliştirme enstitüsü. Gıda Tarım ve Hayvancılık Bakanlı̆̆ı.

Tekeli A. 2014. Hayvan beslemede alternatif protein kaynağı olarak böceklerin kullanımı. Türk Tarım ve Doğa Bilim Derg,1(4): 531-538.

Wang D, Zhai SW, Zhang CX, Bai YY, An SH, Xu YN. 2005. Evaluation on nutritional value of field crickets as a poultry feedstuff. Asian-Australian J Anim Sci, 18 (5): 667670. https://www.worldhunger.org/world-hunger-and-poverty-facts-and-statistics/2018. 
Webster, R. P., DeMerchant, I., New Coleoptera records from New Brunswick, Canada: Dryopidae, Elmidae, Psephenidae, and Ptilodactylidae. ZooKeys 179: 67-75, (2012). 